\title{
FARKLI PASTÖRİZASYON KOŞULLARININ BEYAZ PEYNİRİN REOLOJİK, TEKSTÜREL VE DUYUSAL ÖZELLİKLERİNE ETKİSİ
}

\author{
Oğuz Aydemir ${ }^{1}$, Abdullah Kurt ${ }^{2 * *}$ \\ ${ }^{1}$ Çankırı Karatekin Üniversitesi, Mühendislik Fakültesi, Gıda Mühendisliği Bölümü, Çankırı, Türkiye \\ ${ }^{2}$ Selçuk Üniversitesi, Akşehir Mühendislik ve Mimarlık Fakültesi, Gıda Mühendisliği Bölümü, Konya, Türkiye
}

Geliş / Received: 08.09.2020; Kabul / Accepted: 19.10.2020; Online bask1 / Published online: 30.10.2020

Aydemir, O., Kurt, A. (2020). Farklı pastörizasyon koşullarının beyaz peynirin reolojik, tekstürel ve duyusal özelliklerine etkisi. GIDA (2020) 45 (6): 1083-1096 doi: 10.15237/gida.GD20101

Aydemir, O., Kurt, A. (2020). The effect of different pasteurization conditions on the rheological, textural and sensory properties of white cheese. GIDA (2020) 45 (6): $1083-1096$ doi: 10.15237/gida.GD20101

\section{ÖZ}

Bu çalışmada, farklı koşullarda pastörize edilen sütten (A: $65^{\circ} \mathrm{C}$ 'de 20 dak, B: $75^{\circ} \mathrm{C}$ 'de 5 dak ve C: $85^{\circ} \mathrm{C}$ 'de 5 dak.) üretilen Beyaz peynirlerin dinamik reolojik, tekstür, renk ve duyusal özellikleri 7., 30., 60. ve 90. günlerde araşıırılmıştır. C ve B peynirlerinin, A'dan daha yüksek elastik özellikleri, sıcaklığa bağlı kazeinin molekül içi ve moleküller arası etkileşimlerinin gelişmesine ve bu yapıdaki denatüre peynir altı suyu yüzdesinin artmasına bağlanmışır. Depolama sırasında viskoelastik özelliği ve kompleks viskozite parametresi en fazla A peynirinin değişirken, B peynirinin daha kararlı olduğu belirlenmiştir. Tekstür analizindeki sertlik ve dış yapışkanlık sonuçları da B peynirinin daha dirençli protein yapısına sahip olduğunu göstermiştir. Farklı pastörizasyon sıcaklıklarının, renk parametreleri üzerine bir etkisi bulunmamıştır. B peynirinin Yap1-Tekstür özelliği ilk aylarda daha yüksek puan alırken, son ayda örnekler arası fark görülmemiştir. Sonuç olarak, $75^{\circ} \mathrm{C}$ 'de pastörize edilen sütten, viskoelastik özelliği gelişmiş bir Beyaz peynir üretilebilmekledir fakat artan sıcaklık bu karakteri azaltmaktadır.

Anahtar kelimeler: Beyaz peynir, pastörizasyon sıcaklığı, reoloji, tekstür

\section{THE EFFECT OF DIFFERENT PASTEURIZATION CONDITIONS ON THE RHEOLOGICAL, TEXTURAL AND SENSORY PROPERTIES OF WHITE CHEESE}

\begin{abstract}
In this study, dynamic rheological, textural, color and sensory properties of White cheeses produced from pasteurized milk at different conditions $\left(\mathrm{A}: 65^{\circ} \mathrm{C}\right.$ for $20 \mathrm{~min}, \mathrm{~B}: 75^{\circ} \mathrm{C}$ for $5 \mathrm{~min}$, and C: $85^{\circ} \mathrm{C}$ for $5 \mathrm{~min}$ ) were investigated at 7, 30, 60, and 90 days of storage. The higher elastic behaviors of the cheeses $\mathrm{C}$ and $\mathrm{B}$ than $\mathrm{A}$ were associated with improved inter- and intramolecular interactions of casein related to the temperature and an increase in the ratio of denatured whey protein in this structure. Cheese A changed as the highest extent in viscoelastic property and complex viscosity parameter while cheese B was determined as more stable during storage. The results of hardness and adhesiveness in texture analysis confirmed that cheese B had a more resistant protein structure. The effect of different pasteurization temperatures on the color parameters was not found. The Structure-
\end{abstract}

\footnotetext{
${ }^{*}$ Yazışmalardan sorumlu yazar / Corresponding author;

abdullah.kurt@selcuk.edu.tr

(c) (+90) $3328140134 / 2010$

县 $(+90) 3328140133$
}

Oğuz Aydemir; ORCID no: 0000-0003-0538-2311

Abdullah Kurt; ORCID no: 0000-0003-1452-3278 
Texture as a sensory property of cheese B in the first months received higher scores while no differences among the samples in the last month were observed. As a result, White cheese with improved viscoelastic property could be produced from the milk pasteurized at $75{ }^{\circ} \mathrm{C}$ but increased temperature reduced this feature.

Keywords: White cheese, pasteurization temperature, rheology, texture

\section{GİRIŞ}

Süt, mikrobiyolojik açıdan güvenli hale getirilmesi için $72{ }^{\circ} \mathrm{C}$ 'de $15-35$ s pastörize edilmektedir. 72 ${ }^{\circ} \mathrm{C}$ 'nin üzerindeki pastörizasyon işlemi, pihtı oluşumunu ve sineresizi olumsuz etkilediğinden genellikle peynir üretim uygulamalarında tercih edilmez (Rynne vd., 2004). $70{ }^{\circ} \mathrm{C}$ üzerindeki 1s1 işlem uygulamaları, $\beta$-laktoglobulin ve $\alpha$ laktalbumin gibi önemli serum proteinlerinin denatürasyonuna ve bunlarin $x$-kazein ile kimyasal etkileşimine neden olmakta ve artan sicaklik ile gelişen bu durum peynir üretiminde rennetin, kazein substratı üzerindeki etkinliğini düşürebilmektedir. Kessler, (1996)'e göre 82-95 ${ }^{\circ} \mathrm{C}$ 'de 80-360 s 1sıl işlem koşulları, sütteki serum proteinlerinin denatürasyon oranını \%90'n üzerine çıkarmaktadır. Ayrıca artan 1 sıl işlem sicaklığ1 kalsiyum, magnezyum ve fosfat iyonlarının çözünür halden kolloidal forma geçmesine neden olmaktadır (Fox vd., 2015; Singh ve Waungana, 2001). Bununla birlikte serum proteinlerinin etkili bir şekilde geri kazanımını sağlaması ile peynir verimini arttırma potansiyeli nedeniyle yüksek pastörizasyon sıcaklığının etkisi de çalışılmaktadır. Peynire serum proteinlerinin dâhil olması, besin değeri artışını, peynir veriminin yükselmesini ve özellikle düşük yağlı peynirlerde duyusal yönden gelişimi sağlamaktadır. Aynı zamanda peynir altı suyunun değerlendirilmiş olması ekonomik açıdan önem katmaktadır. Serum proteinlerinin pihtıya dâhil olmasından fayda sağlamak için peynir üretim koşulları, yüksek kalitede bir peynir üretmek için peynire işlenecek sütün bileşimi ve ürünün gereksinimlerine uygun uyarlamaları gerektirmektedir. Proses açısından, peynirin viskoelastik özelliklerine etkisi en yüksek olan parametre pastörizasyon sıcaklı̆̆ıdır (Frau vd., 2014). Yüksek pastörizasyon sicaklığ1 yaklaşımı, tekstürel açıdan olumsuz bir ürün yerine yüksek miktarda değerli serum proteini içeren ve kremsi ya da yumuşak yapıda yenilikçi peynir ürünleri ortaya çıkarma firsatı sunması açısından da üzerinde çalısıllması gereken bir konudur (Benfeldt vd., 1997). Rynne vd., (2004), sütün pastörizasyon sıcaklığındaki artışı, Cheddar peynirindeki denatüre olmuş serum proteini ve nem miktarlarında artışa ancak yă miktarlarında ise azalmaya neden olduğunu bildirmişlerdir. Ayrıca, pastörizasyon sıcaklığının yükselmesine paralel olarak peynir sertliğinde ve kırlma geriliminde olan azalmalar, kuşkusuz az-yağl1 peynirlerin tekstürel ve reolojik özelliklerinin düzeltilmesinde faydalı olacağı belirtilmiştir.

Peynirlerin üretim sonundaki ve depolama sırasındaki reolojik ve tekstürel değişimleri peynir kalitesi üzerinde oldukça önemli bir etkiye sahiptir. Olgunlaşma sırasında reolojik ve tekstürel açıdan peynirin yapısında meydana gelen değişiklikler protein bağlarının kırılıp yeniden bağlanmas1 temelinde dinamik bir şekilde gelişmektedir. Bu etki hem taşıma ve depolama stabilitesi açısından hem de tüketici tercihi bakımından üretici firmaların göz önünde bulundurmasi gereken elzem kriterlerdendir. Bu nedenle objektif reolojik ve tekstürel araştırmalar, tüketicilerin farklı beklentilerinin bilimsel temeller ışığında standardize edilerek ölçülüp değerlendirilmesini sağlaması açısından son derece önemli analizlerdir. Özellikle peynirlerin mikroyap1 ile reolojik özellikler arasındaki ilişkilerin belirlenmesi farklı reolojik özellikte peynir üretim beklentilerine cevap vermeyi tesadüflere birakmayacaktır (Ak ve LokumcuAltay, 2011).

Yurtdışında bazı peynir tipleri için verim, bileşim, tekstürel özellikler ve proteoliz üzerine pastörizasyon sıcaklığının etkisi konusunda çalışmalar yapılmakla birlikte ülkemize özgü peynirlerden en önemlisi olan Beyaz peynirde böyle bir çalışma yapılmamıştır. Ayrıca günümüzde marketlerde gördüğ̈̈müz "lokum kıvamında" peynir olarak üretilen yenilikçi Beyaz peynirler bu şekilde üretilmektedir. Bu tip Beyaz 
peynirle ilgili bilimsel bir çalışmaya da rastlanmamıştır. Üretim yöntemine bağlı olarak firmadan firmaya farklı tekstürel özelliklere sahip Beyaz peynirler elde edilmektedir. Bu konuda etkin bir standardımız yoktur. Üretici firmalar kendine uygun yöntemlerle üretimini gerçekleştirmekte ve sonuçta birbirinden çok farklı duyusal özelliklere sahip Beyaz peynirler piyasada yer almaktadır. Gelişmiş ülkeler, peynirlerine ait bu tür standardizasyonlarını hâlihazırda gerçekleştirmişlerdir. $\mathrm{Bu}$ konuda ülkemizde bir boşluk söz konusudur. Bu çalışma çift cidarlı pastörizatörde süte uygulanan farklı sıcaklık ve süre koşullarının, Beyaz peynirin dinamik reolojik, tekstür, renk ve duyusal özellikleri üzerine etkisini belirlemeyi amaçlamaktadır.

\section{MATERYAL VE YÖNTEM}

\section{Peynir üretimi}

Peynir üretimleri Atatürk Orman Çiftliği Süt İşletmesi'nde (Ankara, Türkiye) gerçekleştirilmiştir. Her bir üretim için $500 \mathrm{~L}$ inek sütü kullanılmıştır. Sütün pastörizasyonu çift cidarlı pastörizatörde 3 farklı sıcaklık ve sürede yapılmışır: $65^{\circ} \mathrm{C}$ 'de 20 dak, $75^{\circ} \mathrm{C}$ 'de 5 dak ve 85 ${ }^{\circ} \mathrm{C}$ 'de 5 dak. $\mathrm{Bu}$ sütlerden üretilen peynirler sırasiyla A, B ve C olarak kodlanmıştır. Pastörizasyonun ardından $35^{\circ} \mathrm{C}$ 'ye soğutulan süte $\% 1$ oranında starter kültür [Lactococcus lactis subsp. lactis, L. lactis subsp. cremoris, ve Streptococcus thermophilus (Benofer BP-1, Benosen, Türkiye)] ilavesi yapılmıştır. $30 \mathrm{dk}$ inkübasyon sonrası sütlere $\% 0.02$ oranında $\mathrm{CaCl}_{2}$ (Solvay, İtalya) eklenmiştir. Aktivitesi belirlenmiş buzağı renneti (Naturen Mandra 175, Chr. Hansen, Türkiye) ile $34{ }^{\circ} \mathrm{C}$ 'de 90 dak'da pihtı kesim olgunluğuna gelecek şekilde mayalama işlemi gerçekleştirilmiştir. Pıhtı kırılıp, peynir altı suyu ayrildıktan sonra cendere bezinde baskiya alınan pihtı daha sonra porsiyonlanmıştır $\left(8 \times 8 \times 8 \mathrm{~cm}^{3}\right)$. Salamuraya $\left(11.5^{\circ}\right.$ Bome) alınan peynir kalıplar1 $20{ }^{\circ} \mathrm{C}^{\prime}$ de 3,5 saat salamurada kalmıștır. Daha sonra kapama pH'sına (4.8) ulaşan peynirler ambalaj kutularına doldurulmuş ve salamura eklenerek ( $9{ }^{\circ}$ Bome) kapatılmıştır. 90 gün boyunca peynirler $5 \pm 1$ 'de depolanmıştır. Üretim 2 tekerrür ile yapılmıştır.

\section{Dinamik reolojik analiz}

Bu çalışmada reolojik analizler HAAKE Marrs III (Thermo Scientific, Almanya) reometre cihazı ile (Kahyaoglu ve Kaya, 2003) yöntemine göre yapılmıştır. Ölçümler konik plakalı (35 mm çap, ve $2^{\circ}$ açı) geometri ile yapılmıştır. Peynir örnekleri, çapları $35 \mathrm{~mm}$ ve kalınlıkları $1 \mathrm{~mm}$ olacak şekilde disk şeklinde kesilmiş, analize kadar su kaybını engellemek için streç film ile sarrlarak oda sıcaklığında 1 saat süresince bekletilerek ölçüm öncesi dengelenmesi sağlanmıştır. Sicaklık kontrollü peltier sistem aracillğıyla viskoelastik analizler $20^{\circ} \mathrm{C}$ 'de yapılmıştır. Frekans tarama testi lineer viskoelastik aralıkta yapılmıştır. $10 \mathrm{~Pa}$ gerilimde $0.1-100 \mathrm{~Hz}$ aralığ taranarak elastik $\left(G^{\prime}\right)$ ve viskoz $\left(G^{\prime \prime}\right)$ bileşenlerin değerleri belirlenmiştir. $\mathrm{Bu}$ bileşenler ve kompleks viskozite $\left(\eta^{*}\right)$ değişkenlerinin, açısal hızın $(\omega, \mathrm{rad} / \mathrm{s})$ fonksiyonu olarak üssel model parametreleri aşağıdaki denkliklere göre belirlenmiştir.

$$
\begin{aligned}
& G^{\prime}=K^{\prime} \omega^{\mathrm{n}^{\prime}} \\
& G^{\prime \prime}=K^{\prime \prime} \omega^{\mathrm{n}^{\prime \prime}} \\
& \eta^{*}=K^{*} \omega^{n^{*}-1}
\end{aligned}
$$

\section{Tekstür analizi}

Tekstür profil analizi (TPA), silindir şeklinde ( $30 \pm 5 \mathrm{~mm}$ çap ve $20 \pm 5 \mathrm{~mm}$ yükseklik) kesilen peynirlere, Tekstür Analiz cihazı (TA-XT32, Stable Micro System, Godalming, İngiltere) kullanılarak oda sıcaklığında yapılmıştır. SMS $\mathrm{P} / 36$ silindirik prob kullanılarak, test öncesi, sıras1 ve sonrası hizlar1 $1 \mathrm{~mm} / \mathrm{s}$ ile $\% 25$ deformasyona izin verecek şartlarda analiz yapılmıştır. İki ardışık sıkıştırma ile elde edilen, kuvvet zaman grafiğindeki veriler, cihazın yazılımı ararcılloğıla sertlik (hardness; g), diş yapışkanlık (adhesiveness; gs), elastikiyet (springiness; mm), iç yapışkanlık (cohesiveness), sakızımsılık (gumminess; g) ve çiğnenebilirlik (chewiness; gmm) parametrelerinin belirlenmesinde kullanılmıştır.

\section{Renk analizi}

Peynir örneklerinin $L^{*}$ (açıklık-koyuluk, 100:beyaz, 0:siyah), $a^{*}(+:$ kırmızı $(+100)$, -:yeşil $(-$ $80), 0$ :gri), $b^{*}(+$ :sar1 (+70), -:mavi (-80), 0:gri) ve bu parametrelerden türetilen beyazlık indeksi 
$(W I)$, Kroma $\left(C^{*}\right)$ ve Hue $\left(b^{\circ}\right)$ değerlerinin belirlenmesi için renk ölçer (CR-400, Konica Minolta, Japonya) cihazı kullanılmıştır. İkincil parametrelerin hesaplanmasinda aşağıdaki denklikler kullanılmıştır (Sant'Anna vd., 2013).

$$
\begin{aligned}
& W I=100-\sqrt{\left(100-L^{*}\right)^{2}+\left(a^{*}\right)^{2}+\left(b^{*}\right)^{2}} \\
& C^{*}=\sqrt{a^{*^{2}}+b^{*^{2}}} \\
& h^{\circ}=180+\arctan \left(b^{*} / a^{*}\right)\left[\left(-\mathrm{a}^{*},+\mathrm{b}^{*}\right)\right]
\end{aligned}
$$

\section{Duyusal analiz}

Peynirlerinin duyusal değerlendirmesi (7., 30., 60. ve 90. günlerde), Çankırı Karatekin Üniversitesi Mühendislik Fakültesi öğretim elemanlarından oluşan 10 kişilik kısmi eğitilmiş panelist grup tarafından gerçekleştirilmiştir. Analiz öncesi panelist grup değerlendirme ve kusurlar hakkında bilgilendirilmiştir. Tat-Aroma 10, Yap1-Tekstür 5, Görünüş-Renk ise 5 puan üzerinden değerlendirmek amaciyla puan kartları hazırlanmıştır. Örnekler 3 haneli rastgele rakamlarla kodlanarak yine panelistlere rastgele sirada sunulmuştur. Duyusal analiz sırasında peynirlerin sıcaklığının $10-15{ }^{\circ} \mathrm{C}$ ler arasında olması sağlanıp, örnekler arasında panelistler ağız tadını elma ve/veya üzüm ve su ile dengelemişlerdir.

\section{İstatistiksel analiz}

Analizlerin ortalama ve standart sapma değerleri hesaplanmıştır. Tek yönlü varyans analizi (ANOVA) SPSS paket programı (SPSS 16.0) ile hesaplanmıştır. Çoklu karşılaştırma Tukey testi ile yapilmıştır $(P<0.05)$.

\section{SONUÇ VE TARTIŞMA \\ Dinamik reolojik analiz}

Süte uygulanan farklı sıcaklık normlarının, beyaz peynirin viskoelastik özelliklerine etkisini ve bu özelliğin depolama süresince değişimini belirlemek için frekans tarama testleri lineer viskoelastik alanda yapılmıştır. Dinamik reolojik analizler, örneği tahrip etmeden, gerilimin harmonik olarak uygulanması yoluyla viskoelastik özelliklerin belirlenmesinde yaygın olarak tercih edilen bir analiz yöntemidir (Park vd., 2007). $G^{\prime}$ değeri diğer bir ifadeyle depolama modülü, uygulanan gerilime bağlı olarak, örneğin yapısında depolanan ve daha sonra serbest birakilan enerjiyi gösterirken, $G^{\prime \prime}$ değişkeni ise analiz edilen örneğin viskoz yanıtı olup uygulanan gerilime bağl1 kaybolan enerjidir ve kayip modül olarak da adlandırılmaktadır (Gunasekaran ve Ak, 2000). Peynir örneklerinin, elastik $\left(G^{\prime}\right)$ ve viskoz $\left(G^{\prime \prime}\right)$ bileşenlerinin frekansa bağlı değişimleri Şekil 1'de sunulmuştur. $G^{\prime}$ ve $G^{\prime \prime}$ değerlerinin frekansa bağlı değişim göstermesi, peynirlerin viskoelastik karakterde olduğunu ve frekans taraması boyunca, $G^{\prime}>G^{\prime \prime}$ olmas1 ise peynirlerde elastik özelliğin hakim olduğunu göstermektedir (Drake vd., 1999). tan $\delta$ değerinin 1'den küçük olması peynirlerin viskoelastik özelliklerinin bir diğer kanıtıdır. Taze peynirlerde $G^{\prime}>G^{\prime \prime}$ olması durumu peynirin, yüksek protein ve kül (özellikle kalsiyum) miktarı ile düşük yağ miktarına sahip olması ile ilişkilendirilmektedir (Joshi vd., 2004). Proteinlerin 1s1 etkisiyle denatürasyonu ile gelişen kimyasal etkileşim sonucu oluşan ve içerisinde suyu bağlama özelliğine sahip protein bazlı elastik ağ yap1, peynirin elastik karakterinden sorumludur (Rubel vd., 2019). Frekansa bağl1 modüllerdeki değişim, materyal olarak değerlendirildiğinde peynirin zayıf jel grubunda olduğunu göstermektedir. Beyaz peynir, proses edilen peynirler ve polimer kaynakl jeller de genel olarak bu grupta yer almaktadır (Jooyandeh vd., 2017; Kahyaoglu ve Kaya, 2003). G' değerinin frekansa bağlı olarak artış göstermesi, kazein partiküllerinin molekül içi ve moleküller arası etkileşimler ile birleşerek yüzey alanının artması sonucu yeni proteinlerin bu yapiya eklenmesinin teşvik edilmesi ile açılanmaktadır (Florencia, 2013). Viskoelastik parametrelerin frekansa bağlı değişim göstermesi aynı zamanda yapidaki kimyasal etkileşimde (hidrofilik, hidrofobik, elektrostatik etkileşimler ve kovalent bağ gibi) kovalent ve disülfit bağlarının diğer etkileşimlerden daha baskın olmadığını da göstermektedir (Spotti vd., 2014). Dolayısıyla, bu çalışmadaki peynirlerin zayıf mikroyapıda olduğu ve yumuşak peynirler sınıfinda olduğu söylenilebilir (Van Hekken vd., 2012).

Peynirin viskoelastik özellikleri yapıdaki kazein miktarından ve kazein matriksi içerisinde yer alan kimyasal bağlardan etkilenmektedir (Guo vd., 
2011). Süte uygulanan sicaklik derecesinin kazenin yapısını etkilediği ve depolama süresince de proteolize bağlı kazeindeki kimyasal etkileşimin farklılaştı̆ı görülmektedir (Şekil 1). $G^{\prime}$ ve $G^{\prime \prime}$ değerleri 7. günün sonunda 5-7 kPa seviyelerinde iken depolama ile birlikte $0.5-1 \mathrm{kPa}$ düzeyine düşüşü daha önceki peynir çalışmaları ile uyumludur (Kahyaoglu ve Kaya, 2003; RamírezLópez ve Vélez-Ruiz, 2018; Van Hekken vd., 2012).

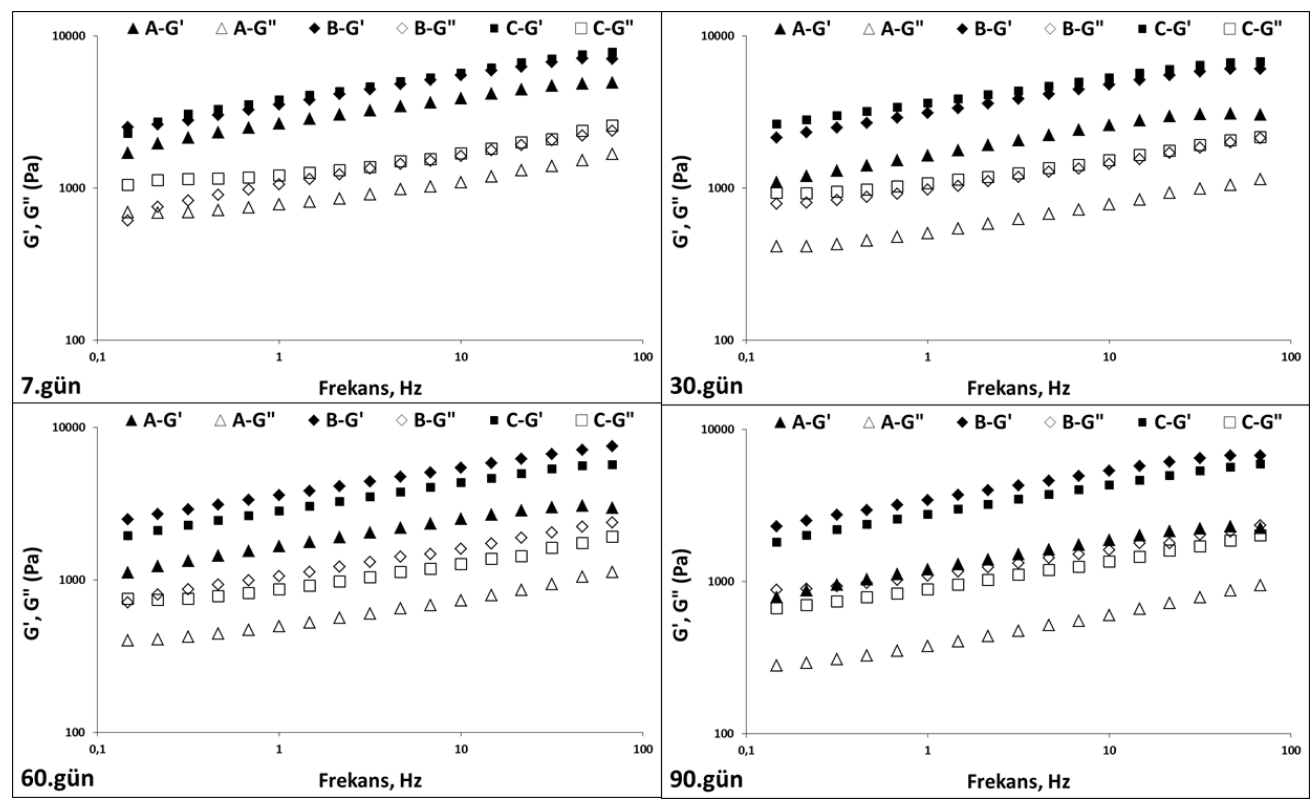

Şekil 1. Beyaz peynirlerin frekans tarama testlerinin depolama süresince değişimi

Figure 1. Frequency sweep tests variation of White cheeses during storage

C ve B peynirlerinin ilk hafta sonunda elastik $\left(G^{\prime}\right)$ özelliklerinin birbirine benzer olduğu, A peynirinin ise elastik özelliğinin daha düşük olduğu bulunmuştur. C ve B peynirlerinin yüksek elastik özelliği, kazeinin molekül içi ve moleküller arası etkileşimlerinin yüksek pastörizasyon sıcakllğ1 ile değişmesi sonucu kazein partiküllerinin birleşme yoğunluğundaki artış ile açıklanabilir (Fox vd., 2004). Ayrıca, süte uygulanan yüksek pastörizayon sıcaklığının son ürünün yapısal sıkılık (firmness) özelliğini arttırmas1; denatüre peynir altı suyu proteinlerinin miktarının sıcaklık ile artarak bunların kazein misellerine bağlanma yüzdesini geliştirmesi sonucu hem peynirdeki protein miktarının artması hem de peynirin elastik özelliğinin gelişmesi yani deformasyona karşı direncinin artması ile açıklanabilir (Guinee vd., 1993). Başlıca kimyasal etkileşimler disülfit ve hidrofobik etkileşimler ile $\beta$-laktoglobulin ve $x$-kazein arasında olmaktadır. Ancak peynir altı suyu protein çeşitlerinin 1sıya duyarlllıklarına göre [immunoglobulinler $>$ bovin serum albumin $>\beta$-laktoglobulin $(\beta-\mathrm{Lg})>\alpha-$ laktoalbumin $(\alpha-\mathrm{La})]$ denatüre olan fraksiyonları, kazein ile etkileşim gösterirken tiyol-disülfit yer değiştirme reaksiyonları, hidrofobik etkileşimler ve iyonik bağlanmalar gerçekleşmektedir (Singh ve Waungana, 2001). Gerilim direncinin ve yapisal sıkılığın yüksek olması düşük yağ miktarı ile de ilişkilendirilmektedir. Çünkü yağ, protein matriksinde kayganlaştırıcı etki göstermektedir ve fazla olduğu sistemin kazein proteinleri aras1 etkileșimini azaltarak peynirin kırılma geriliminin düşmesine neden olmaktadır (Guinee vd., 2000). Pastörizasyon sıcaklığındaki artış ile birlikte peynirin kuru madde miktarının artması ve buna bağlı olarak da yağ içeriğinde azalma peynir üretiminde gözlenen bir sonuçtur (Frau vd., 2014). $\mathrm{Bu}$ nedenle A peynirinin düşük viskoleastik özelliği, C ve B’ye göre yağ içeriğinin yüksek olmasına da bağlanılabilir. Cheddar peynirlerinin yüksek yağ içermesi durumunda gerilim direncinin ve yapısal sıkıllğının azaldığ 
daha önceki bir çalışmada rapor edilmiştir (Guinee vd., 2000).

Viskoz bileşen $\left(G^{\prime \prime}\right)$ peynir matriksi içerisindeki bileşenlerin hareket edebilme veya akma yeteneğini göstermektedir. 7 günlük depolama sonundaki peynirlerin bu bileşeni, peynir çeşitleri için benzer özellik gösterirken, depolama boyunca bu bileşende düşüşün görüldügü süreçte $\mathrm{C}$ ve $\mathrm{B}$ benzer viskoz karaktere sahip olurken A peyniri zamanla en düşük viskoz karakterdeki peynir olmuştur. A peynirine kıyasla, viskoz karakterin, peynirin genel viskoelastik yapısındaki rolünün depolama süresince $\mathrm{C}$ ve $\mathrm{B}$ peynirlerinde daha yüksek olması, uygulanan yüksek sıcaklığın olumlu bir sonucudur.

Dinamik viskoelastik analiz parametreleri, peynir matriksindeki toplam bağ sayısı ve bağların kuvvetini de göstermektedir (Lucey vd., 2003). Depolama süresince viskoelastik özelliklerin değişimini yorumlamak için modüllerin değişimi açısal hızın fonksiyonu olarak üssel modele uyarlanmıştır $\left(\mathrm{R}^{2}>0.99\right)$ ve $K^{\prime}$ ve $K^{\prime \prime}$ parametrelerinin zamana bağlı değişimleri Şekil 2'de sunulmuştur. Depolamaya bağlı olarak proteoliz nedeniyle toplam bağ sayısı ve kuvvetin peynir matriksinde azalması nedeniyle parametrelerde düşüş görülmüştür. Proteoliz ile peptid bağlarında kırılma ile oluşan yeni iyonların proteinlerin su tutma kapasitesi arttırması sonucu toplam kuru madde miktarında azalma (i) ve hidrolize olan protein fraksiyonlarının salamuraya geçişi ile peynir protein miktarında azalma (ii) viskoelastik özellikteki düşüşün bağlanabileceği diğer nedenlerdir (Atasoy ve Türkoğlu, 2008). Süte uygulanan farklı pastörizasyon sicaklık normlar1, peynirlerin bu değerlerinin düşüş eğilimlerinde değişikliklere neden olmuştur. Yüksek pastörizasyon sıcaklığından kaynaklı doğrusal olmayan kazein molekülleri arası çapraz bağların sayısının fazla olması nedeniyle $B$ ve $C$ peynirlerinin daha s1k1 bir peynir yapısında olduğu düşünülmektedir (Soltani vd., 2016). En düşük parametre değerlerine sahip A peynirinin, depolama süresince de bu parametrelerdeki düşme eğilimi de yüksek olmuştur. İlk ayda C peynirine göre $K^{\prime}$ ve $K^{\prime \prime}$ değerleri B için düşük bulunmuştur. Fakat B peynirinde parametreler depolamaya bağlı olarak önemli bir düşüş sergilememiştir ve ikinci ayda önemli düşüşün başladığı $\mathrm{C}$ peynirine göre parametre değerleri daha yüksek bulunmuştur. A peynirinde proteolitik aktivite yüksek iken (veri gösterilmemiştir) $\mathrm{B}$ ve $\mathrm{C}$ peynirlerinin bu aktiviteye direnci yüksek bulunmuş ve depolama boyunca B peyniri daha kararlı bir özellik ortaya koymuştur. C peynirindeki 2. aydan sonra görülen önemli miktardaki düşüş ise $\mathrm{B}$ peynirine göre kazein proteinleri arasında gömülmüş halde bulunan denatüre peynir altı suyu proteininin fazla olmas1 nedeniyle kazein proteinleri aras1 etkileşimin ve sürekliliğin proteolitik aktivite ile daha fazla düşüş göstermesi ile açılanabilir (Rynne vd., 2004). Denatüre peynir altı suyu proteinlerinin ve çeşitlerinin peynirin toplam proteinindeki oranının başlangıç ve depolama sırasında beyaz peynirin viskoelastik özelliklerini ve depolama stabilitesini etkilediği anlaşılmaktadır.

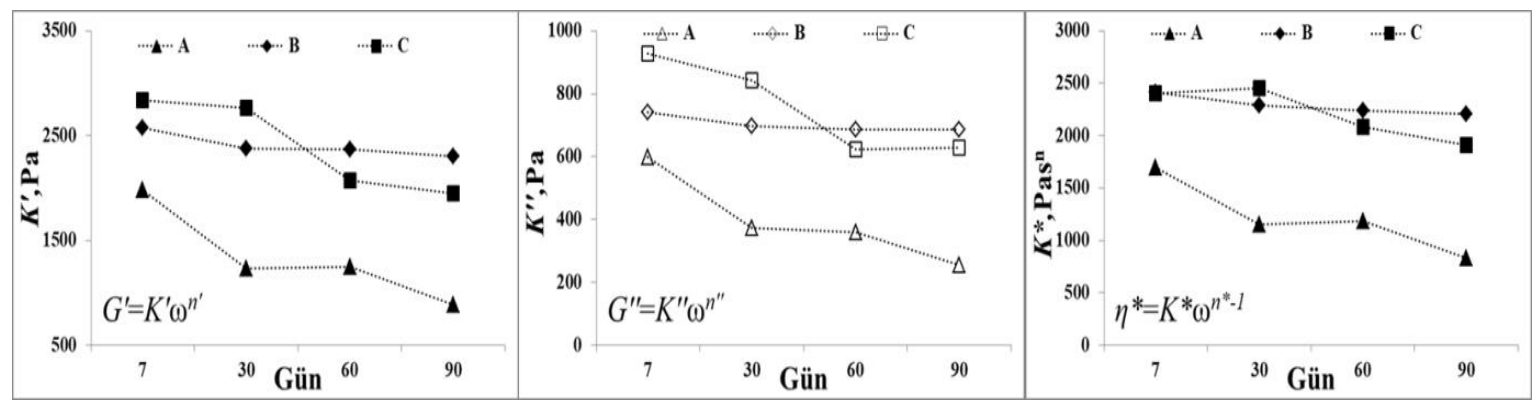

Şekil 2. Beyaz peynirlerin elastik $\left(G^{\prime}\right)$, viskoz $\left(G^{\prime \prime}\right)$ ve kompleks viskozite $\left(\eta^{*}\right)$ bileşenlerinin üssel model parametrelerinin depolama süresince değişimi

Figure 2. The variation in the Pawer law model parameters of elastic $\left(G^{\prime}\right)$, viscous $\left(G^{\prime \prime}\right)$ and complex viscosity $\left(\eta^{*}\right)$ of White cheeses during storage 
Kompleks viskozite akmaya karşı direncin ölçüsü olup kompleks modülün açısal hıza bölünmesi ile bulunur. Kompleks viskozitenin açısal hızın fonksiyonu olan akış grafiği, kayma gerilimine bağlı viskozite grafiği ile benzerlik gösterdiğinden, peynir gibi materyallerin viskoziteleri hakkında fikir edinebilmek için kompleks viskozite kullanılmaktadır (Giri vd., 2018). Ostwald-de Waele denkliği elde edilen sonuçlann modellenmesinde kullanılmıştır ve depolamaya bağlı model parametrelerindeki değişim Şekil 2'de gösterilmiştir. 0.1-0.4 arasında değişen $n^{*}$ değerleri peynirlerin pseudo-plastik karakterde olduğunu göstermektedir.

Viskozitenin bir ölçüsü olan konsistens katsayısı $\left(K^{*}\right)$, dinamik viskozite parametreleri ile benzer değişim sergilemiştir. B peynirinin viskozitesi depolama süresince özelliğini korurken A peynirinde 2. ay itibariyle önemli düşüş başlamıştır. Benzer viskozite azalmasının görüldüğü Feta peynirlerinde bu düşüş, proteolizin ileri safhasında gerçekleşen laktik asit bakterileri kaynakli proteaz ve peptidaz aktiviteleri ile büyük oligopeptid yapılarının daha küçük peptid ve aminoasit moleküllerine dönüşmesi ile açıklanmıştır (Farbod vd., 2013). Proteolizin bu safhası A peynirinde ise ilk ayda görülmüştür. Dolayısıyla süte uygulanan yüksek 1 sıl işlemi viskozite stabilitesini arttırırken ileri düzey sıcaklikların denatüre peynir altı suyu proteinin artışından kaynaklı stabiliteyi azaltıcı etkisi ortaya çıkmaktadır.

\section{Tekstür analizi}

Gıdaların tekstür özellikleri, tüketim sırasında dokunma ve çiğneme yoluyla hissedilen kalite parametresi olduğu gibi tüketim öncesi paketleme, taşıma ve depolama koşullarındaki direnci bakımından da önemlidir. Tekstür Profil Analiz (TPA) parametreleri Çizelge 1'de gösterilmiştir. Ölçüm sırasında hedeflenen deformasyon için gerekli en yüksek kuvveti ifade eden sertlik değeri üzerine ve depolama sırasındaki değişim eğilimine pastörizasyon sıcaklığının etkili olduğu görülmüsstür. İlk hafta sonunda peynirlerin sertlik değeri 13-16 N arasında değissiklik göstererek $\mathrm{C}>\mathrm{B}>\mathrm{A}$ şeklinde sıralanmıştır. $\mathrm{Bu}$ sıralama dinamik reolojik özellikler ile uyumlu olup kazeinin molekül içi ve moleküller arası etkileşimlerinin yüksek pastörizasyon sıcaklığı ile daha yoğun gerçekleştiğini ve peynir yapısındaki denatüre protein yüzdesinin sıcaklık ile artış göstererek toplam protein miktarını arttırdığı ve deformasyona karşı direncin genel peynir yapısında geliştiğini doğrulamıştır. Protein oranı ile peynirin sertliği arasında pozitif bir ilişki olduğu belirtilmiştir (Koca ve Metin, 2004). Depolama boyunca peynir çeşitleri farklı değişimler göstermiştir. A peynirinde düzenli bir düşüş 3 . ayın sonuna kadar devam ederken B peynirinin sertlik değerini koruduğu, ilk ay sertlik değeri düşen $C$ peynirinin ise devam eden süreçte bu değerinin değişmediği ve $\mathrm{B}$ peynirine göre daha yumuşak hale geldiği belirlenmiştir. Bu nedenle proteolitik aktivitenin depolama sirasinda A peynirinde en yüksek iken $B$ peynirinde en düşük olduğu ve bu peynirin proteolotik aktiviteye daha dirençli sıkı bir jel ağ yapısına sahip olduğu söylenilebilir. Bu sonuç, dinamik reolojik analizler ile uyumlu olarak, B peynirinde A'ya göre daha az yağ bulunmasina ve C'ye göre ise daha az denatüre peynir alt1 suyu protein varluğına bağlanılabilir. Genel olarak depolama sırasinda peynirin tekstür profil parametrelerindeki değişimler proteoliz, glikoliz, lipoliz ve $\mathrm{pH}$ değişimlerine bağlanmaktadır (Lemes vd., 2016).

Dış yapışkanlık (adhesiveness) peynirin ağızda temas ettiği yüzeyden dil ile uzaklaştırılması için gereken kuvvet olarak ifade edilmektedir (Bryant vd., 1995). Analiz açısından anlamı ise tekstür analizinde kullanılan probun yüzeyden ayrılması için gerekli kuvvettir. Bu değer B peynirinde en yüksek seviyede olup depolama sirasinda istatiksel açıdan önemli bir değişim sergilememiştir ( $P$ $>0.05)$. C peynirinde önemli düşüş son ayda gerçekleşirken $(P<0.05)$, A peynirinde ise depolama boyunca düzenli bir düşüş gözlenmiştir. Genel olarak peynirlerde bu değerdeki azalma yağ ve kuru maddedeki düşüş ile ilişkilendirilmektedir (Bryant vd., 1995). Yağ ve kuru madde bileşenindeki artış nedeniyle depolama sırasında dış yapışkanlık değerinin arttı̆̆ı tespit edilen beyaz peynir ile ilgili çalışma bu teoriyi destekleyen raporlardan biridir (Karaman ve Akalın, 2013). Depolamanın son gününde bu değerin en yüksek seviyede görüldüğü B peynirinin, $C$ peynirine göre daha az kimyasal bileşen değişimi sergilediği düşünülmektedir. 
Çizelge 1. Beyaz peynirlerin TPA parametrelerinin depolama süresince değişimi Table 1. TP A parameters variation of White cheeses during storage

\begin{tabular}{|c|c|c|c|c|c|c|c|}
\hline \multicolumn{8}{|c|}{ Tekstür Profil Analiz Parametreleri } \\
\hline & $\begin{array}{l}\text { Gün } \\
\text { Day }\end{array}$ & $\begin{array}{l}\text { Sertlik } g \\
\text { Hardness } g\end{array}$ & $\begin{array}{c}\text { Diş } \\
\text { Yapışkanlık (-) } \\
\text { gs } \\
\text { Adbesiveness(-)gs }\end{array}$ & $\begin{array}{c}\text { Elastikiyet } \\
\text { mm } \\
\text { Springiness mm }\end{array}$ & $\begin{array}{c}\text { İç Yapışkanlık } \\
\text { Cobesiveness }\end{array}$ & $\begin{array}{c}\text { Sak1z1msilık } g \\
\text { Gumminess } g\end{array}$ & $\begin{array}{l}\text { Çiğnenebilirlik } \\
\text { gmm } \\
\text { Chewiness gmm }\end{array}$ \\
\hline \multirow[t]{4}{*}{$\mathrm{A}$} & 7 & $1353.3 \pm 18.9 \mathrm{~cd}$ & $141.8 \pm 1.3^{\mathrm{e}}$ & $0.87 \pm 0.00^{\mathrm{a}}$ & $0.75 \pm 0.00^{\mathrm{ab}}$ & $1022.4 \pm 15.2^{\mathrm{b}}$ & $892.4 \pm 4.6^{b}$ \\
\hline & 30 & $975.4 \pm 49.8 \mathrm{e}$ & $120.2 \pm 0.3^{\mathrm{f}}$ & $0.86 \pm 0.00^{\mathrm{ab}}$ & $0.72 \pm 0.00^{\mathrm{abc}}$ & $706.7 \pm 35.3^{\mathrm{e}}$ & $613.1 \pm 34.1^{\mathrm{f}}$ \\
\hline & 60 & $713.1 \pm 9.9^{f}$ & $75.67 \pm 2.6 \mathrm{~g}$ & $0.85 \pm 0.00^{\mathrm{abc}}$ & $0.71 \pm 0.00^{\mathrm{bc}}$ & $512.0 \pm 2.0^{\mathrm{f}}$ & $438.8 \pm 4.6 \mathrm{~g}$ \\
\hline & 90 & $714.3 \pm 5.5^{\mathrm{f}}$ & $69.4 \pm 1.9 \mathrm{~g}$ & $0.83 \pm 0.00^{\mathrm{bcd}}$ & $0.71 \pm 0.00^{\mathrm{bc}}$ & $511.8 \pm 8.5^{f}$ & $428.1 \pm 5.3 \mathrm{~g}$ \\
\hline \multirow[t]{4}{*}{$\mathrm{B}$} & 7 & $1461.5 \pm 12.0^{\mathrm{bc}}$ & $258.2 \pm 4.8^{\mathrm{a}}$ & $0.86 \pm 0.00^{\mathrm{a}}$ & $0.71 \pm 0.00^{\mathrm{bc}}$ & $1050.8 \pm 4.5^{b}$ & $913.6 \pm 2.7^{b}$ \\
\hline & 30 & $1511.1 \pm 20.2^{\mathrm{b}}$ & $248.3 \pm 4.6^{\mathrm{ab}}$ & $0.84 \pm 0.00^{\mathrm{abcd}}$ & $0.68 \pm 0.00 \mathrm{~cd}$ & $1028.4 \pm 25.5^{b}$ & $866.8 \pm 12.8^{b c}$ \\
\hline & 60 & $1456.7 \pm 24.2^{b c}$ & $231.2 \pm 6.0^{\mathrm{bc}}$ & $0.84 \pm 0.00^{\mathrm{abcd}}$ & $0.64 \pm 0.00 \mathrm{~d}$ & $945.2 \pm 3.3 \mathrm{bc}$ & $797.8 \pm 5.4 \mathrm{~cd}$ \\
\hline & 90 & $1546.7 \pm 66.4^{\mathrm{ab}}$ & $218.2 \pm 8.7^{c}$ & $0.81 \pm 0.01 \mathrm{~d}$ & $0.51 \pm 0.02^{\mathrm{e}}$ & $800.3 \pm 67.17 \mathrm{de}$ & $652.5 \pm 41.2^{\mathrm{ef}}$ \\
\hline \multirow[t]{4}{*}{ C } & 7 & $1665.0 \pm 23.3^{a}$ & $187.0 \pm 1.2^{\mathrm{d}}$ & $0.87 \pm 0.00^{a}$ & $0.77 \pm 0.00^{\mathrm{a}}$ & $1291.4 \pm 56.9^{a}$ & $1123.7 \pm 55.0^{\mathrm{a}}$ \\
\hline & 30 & $1317.9 \pm 56.5^{\mathrm{d}}$ & $182.0 \pm 3.8^{\mathrm{d}}$ & $0.87 \pm 0.01^{\mathrm{a}}$ & $0.74 \pm 0.00^{\mathrm{ab}}$ & $976.0 \pm 17.6^{\mathrm{b}}$ & $851.5 \pm 3.6^{\mathrm{bc}}$ \\
\hline & 60 & $1368.9 \pm 13.0 \mathrm{~cd}$ & $176.9 \pm 7.6^{\mathrm{d}}$ & $0.85 \pm 0.00^{\mathrm{abc}}$ & $0.74 \pm 0.00^{\mathrm{ab}}$ & $1023.3 \pm 16.5^{b}$ & $871.7 \pm 6.8^{b c}$ \\
\hline & 90 & $1354.3 \pm 13.5^{\mathrm{cd}}$ & $85.6 \pm 0.9 \mathrm{~g}$ & $0.83 \pm 0.00^{\mathrm{bcd}}$ & $0.62 \pm 0.02^{\mathrm{d}}$ & $851.7 \pm 22.1^{\mathrm{cd}}$ & $711.6 \pm 20.3^{\mathrm{de}}$ \\
\hline
\end{tabular}

Değerler ortalama \pm standart sapma olarak verilmiştir.

Aynı sütundaki farklı harflerle gösterilen ortalamalar arasındaki fark istatistiksel olarak anlamlıdır $(P<0.05)$

$V$ alues are given as means \pm standard deviations.

The difference between the means indicated by different letters in the same column is statistically significant $(P<0.05)$

Elastikiyet (springiness) peynir örneğinin ilk sıkıştırma ile deformasyonundan sonra orijinal haline dönme derecesi olarak ifade edilmektedir (Akalın ve Karaman, 2010). 0.82-0.87 aralığında değişen elastik değer daha önceki bir beyaz peynir çalışması sonuçları ile uyumludur (Cankurt, 2019). Depolamanin ilk haftasinda birbirine benzer elastik özellik gösteren peynirler depolamanın 2. ayına kadar istatiksel açıdan değişmemiştir $(P$ $>0.05)$. Depolama süresince de elastikiyet değerinin sabit kalması daha önceki peynir çalışmalarında (Beyaz, kaşar ve feta peynirleri) gözlenen bir sonuçtur ve bu çalışmalarda depolama süresince yağ miktarının değişmemiş olması elastik stabilite ile yağ miktarında artış ise elastikiyette azalma yani elastik özellikteki protein ağ yapısında azalma ile ilişkilendirilmiştir (Ahmed vd., 2016; Eroglu vd., 2016; Jalilzadeh vd., 2018). Ayrıca beyaz peynirlerde yüksek su miktarı da elastikiyetin depolama sirasinda sabit kalmasina bağlanmaktadır (Al-Otaibi ve Wilbey, 2006). Sertlik değeri ve reolojik analizlerdeki çıkarım olan A peynirinin yüksek proteoliz hassasiyetine rağmen elastik özelliğinin iki ay boyunca sabit kalması yüksek su miktarına bağlanmıştır. Proteoliz ile elastikiyet arasında doğrusal korelasyon olmadı̆̆ beyaz peynirler ilgili bir çalışma da rapor edilmiştir (Cankurt, 2019). Olgunlaştırma sırasında elastik parametrenin azalması monokalsiyum ve dikalsiyum para $x$ kazein molekülünden kalsiyum iyonunun salınması sonucu bu moleküllerin yani protein ăg yapısının hidrolizi kaynaklı olduğu belirtilmiştir (Akalın ve Karaman, 2010). Bu durum ancak her bir peynir çeşidi için depolamanın 3. ayında görülmüştür $(P<0.05)$ fakat elastikiyet açısından son ayda örnekler arası fark ortaya çıkmamış olması $(P>0.05)$ pastörizasyon sıcaklığının elastik özellik üzerine etkisinin olmadığını göstermektedir.

İç yapışkanlık (cohesiveness), peynirin çiğneme ile parçalanmadan önceki deformasyonunun ölçüsü veya peynirin 3 boyutlu protein-yağ matriksinin oluşumundan sorumlu iç bağların kuvvetini ifade etmektedir (Ahmed vd., 2016; Karaman ve Akalın, 2013). Bu değerin kuru madde oranı ile doğru orantıll yağ içeriği ile ters orantılı değişim gösterdiği belirtilmiştir (Karaman ve Akalın, 2013). Ancak kimyasal kompozisyon ile iç yapışkanlık arasında birbiri ile uyuşmayan zit ilişkilerin gözlemlendiği çalışmalar da bulunmaktadır (Eroglu vd., 2016). İlk hafta sonunda iç yapışkanlık değeri en yüksek örnek C 
ve A peynirleri depolamanin ilk aylarında ve bazı birbirini takip eden aylarda istatistiksel bir değişim sergilememişlerdir $(P>0.05)$. B peyniri için depolama süresince düzenli bir azalmanın görüldüğü iç yapışkanlık parametresinin sertlik ile negatif korelasyon gösterdiği belirtilmiştir (Lee ve Marshall, 1981). Bu ilişki 3 aylık depolama sonundaki peynir örneklerinde sertlik parametresinin tersi bir sıralama ile bu çalışmada da gözlenmiştir $(A>C>B)$.

Sakızımsılık (gumminess) peynir örneğin yutmaya hazır hale gelmesi sırasında parçalanması için gerekli enerji olarak tanımlanmaktadır. Sertlik ve iç yapışkanlık verilerinin çarpımı ile elde edildiği için sertlik ve iç yapışkanlığ1 etkileyen faktörler sakızımsılık değerini de etkilemektedir. İlk hafta sonunda sertlik ile uyumlu olarak en yüksek sakızımsılık C peynirinde görülürken, 3 aylık depolama sonunda en düşük sakızımsılık ise $\mathrm{A}$ peynirinde görülmüsstür. Depolama sırasında azalma profili de sertlik ile benzer değişim göstermiş̧ir. Dolayısıyla süte uygulanan farklı pastörizasyon sıcaklıklarının protein yapısı ve olgunlaştırma sırasındaki proteolize bağlı değişimi üzerine etkisi bu parametrede de görülmektedir. Artan sicaklık peynirin yutma kivamina gelmesi için gerekli enerjiyi arttırmıştır. Sakızımsılık değerinin esneklik ile çarpılması sonucu, peynirin sertlik özelliğine bağlı değissen bir diğer parametre olan çiğnenebilirlik (chewiness) türetilmektedir. Yutmadan önce gerekli çiğneme sayısı veya bu amaç için yapılan iş olarak ifade edilmektedir ve tüketilen gıdanın tadının algılanmasını etkileyen önemli bir parametredir (Türkmen, 2019). Bu nedenle sertliği etkileyen faktörler bu değeri de etkilediğinden sertlik değeri sakızımsılık ve çiğnenebilirlik gibi TPA analizindeki alt parametrelerin tahmin edilmesini sağlamaktadır. C peynirinin ilk hafta sonunda bu değeri en yüksek seviyede olmuştur ancak depolama sirasinda B peynirinin bu parametresinde azalma eğilimi ilk iki ay daha az olmuştur ve 3 ay sonunda $B$ ve $C$ peynirleri arasında çiğnenebilirlik için istatistiksel açıdan fark ortaya çıkmamıştır $(P$ $>0.05)$. Dolayisiyla yüksek pastörizasyon sicaklığına maruz kalan sütten üretilen bu peynirlerin olgunlaştırma sırasında gerçekleşen protein-protein etkileşimini etkileyen biyokimyasal değişimlere daha dirençli hale geldiği düşünülmektedir.

\section{Renk analizi}

Renk analiz sonuçları Çizelge 2'de sunulmuştur. Peynir yüzeyinden geçiş gösteren 1şığın yağprotein ara-yüzeyinden saçılmasıyla belirlenen renk parametreleri, moleküler ve mikro-yapısal düzeyde heterojenliğe bağlı olarak değişmektedir (Akalın ve Karaman, 2010). Süte uygulanan pastörizasyon sıcaklı̆̆ının $L^{*}$ değeri üzerine önemli bir etki göstermemesi durumu peynirlerin olgunlaştırılması sırasında da devam etmiştir $(P$ $>0.05)$. Depolama sırasında $a^{*}$ değeri B için sabit kalırken $C$ peynirinde ise düşmüştür. Artan pastörizasyon sıcaklığı $\mathrm{C}$ peynir grubunun yeşil renginde artışa neden olmuştur ancak depolamanın genel olarak peynir çeşitlerinde bu rengin değişiminde bir etkisi olmadığ1 görülmüsşür $(P>0.05)$. $b^{*}$ değeri açısından ne peynir çeşitlerinde ne de depolama süresince bir değişim gözlenmemiştir $(P \quad>0.05) . \quad B u$ parametrelerin kombinasyonlariyla türetilen $W I$, $C^{*}$ ve $b^{\circ}$ değerlerinde de değişimler az olup belirgin farkl11ık ortaya koyan bir peynir çeşidinin belirlenmemesi, peynirlerde tüketici algisını olumsuz etkileyecek bir renk değişiminin depolama süresince korunduğunu göstermektedir. $\quad b^{\circ}$ açısı $0^{\circ}$ ve $360^{\circ}$ ler için kırmızıyı, $90^{\circ}, 180^{\circ}$ ve $270^{\circ}$ ler için ise sırasıyla sarı, yeşil ve mavi renge işaret etmektedir (Izli vd., 2014). Bu bakımdan $h^{\circ}$ açıs1 $91-97^{\circ}$ aralığında değişen peynir örneklerin sarı renge yakın olması bir süt ürünü için beklenen ve daha önceki peynir çalışmalarında da gözlenen bir durumdur (Ramírez-López ve Vélez-Ruiz, 2018).

\section{Duyusal analiz}

Farklı pastörizasyon sıcaklanı uygulanmış sütten üretilen peynirlerin depolama süresi boyunca TatAroma, Yap1-Tekstür ve Görünüş-Renk puanları Şekil 3'de birarada sunulmuştur. Her bir peynir çeşidi için Tat- Aroma puanları, depolama süresince azalma göstermesine rağmen istatistiksel değişim gözlenmemiştir $(P>0.05)$. 60 . günde Tat-Aroma açısından en çok beğenilen peynir $\mathrm{A}$ ve $\mathrm{B}$ peynirleri olmuştur. Bu aşamadan sonra depolamanın ilerleyen günlerinde daha düşük puanı olan $C$ peynirinin fark edilen kusuru 
ise "pişmiş tat" olmuştur. Olgunlaştırma periyodu boyunca A ve C peynirlerinin Yap1Tekstür puanlarında düşüş olsa da istatistiksel fark görülmemiştir $(P>0.05)$. 2. aya kadar bu duyusal özelliğin puanı $\mathrm{B}$ peyniri için artarken bu peynir son ayda istatistiksel bir düşüş göstererek $A$ ve $C$ peynirleri ile benzer Yap1-Tekstür özelliği ortaya koymuştur $(P>0.05)$. Depolama periyodunda Görünüş-Renk özelliği A ve B peynirlerinde 2. aya kadar yüksek bulunmuştur fakat son ay önemli bir azalma görülerek C peyniri ile benzer Görünüş-
Renk karakterine ulaşmıştır. Genel olarak peynirlerin depolamanın son ayındaki duyusal analize ait parametrelerinin puanlarında önemli düşüş görülürken A ve B peynirlerinin genel olarak C peynirinden daha yüksek puanlar aldığ1 tespit edilmiştir. TPA analizinin bir kısım parametrelerinde düşük değerler gösteren A peyniri, duyusal değerlendirmede panelistlere diğer peynirlerden belirgin bir farkll11k hissettirmemiştir.

Çizelge 2. Beyaz peynirlerin color parametrelerinin depolama süresince değişimi Table 2. Color parameters variation of White cheeses during storage

\begin{tabular}{|c|c|c|c|c|c|c|c|}
\hline & \multicolumn{7}{|c|}{ Renk Parametreleri } \\
\hline & $\begin{array}{l}\text { Gün } \\
\text { Day }\end{array}$ & $L^{*}$ & $a^{*}$ & $b^{*}$ & $W I$ & $C^{*}$ & $b^{\circ}$ \\
\hline \multirow[t]{4}{*}{ A } & 7 & $94.38 \pm 0.06^{\mathrm{a}}$ & $-0.63 \pm 0.11^{b c}$ & $9.09 \pm 0.34^{\mathrm{a}}$ & $10.70 \pm 0.33^{a}$ & $9.11 \pm 0.35^{\mathrm{a}}$ & $93.95 \pm 0.55^{\mathrm{b}}$ \\
\hline & 30 & $93.84 \pm 0.36^{\mathrm{a}}$ & $-0.52 \pm 0.13^{\mathrm{ab}}$ & $8.47 \pm 1.44^{\mathrm{ab}}$ & $10.49 \pm 1.38^{\mathrm{a}}$ & $8.49 \pm 1.45^{\mathrm{ab}}$ & $93.51 \pm 0.30^{\mathrm{b}}$ \\
\hline & 60 & $93.67 \pm 0.16^{\mathrm{a}}$ & $-0.38 \pm 0.14^{\mathrm{ab}}$ & $8.03 \pm 0.41^{\mathrm{ab}}$ & $10.23 \pm 0.22^{\mathrm{a}}$ & $8.03 \pm 0.41^{\mathrm{ab}}$ & $92.68 \pm 0.86^{\mathrm{bc}}$ \\
\hline & 90 & $93.47 \pm 0.12^{\mathrm{a}}$ & $-0.22 \pm 0.03^{a}$ & $7.38 \pm 0.07^{\mathrm{ab}}$ & $9.85 \pm 0.02^{\mathrm{a}}$ & $7.38 \pm 0.07^{\mathrm{ab}}$ & $91.74 \pm 0.29 c$ \\
\hline \multirow[t]{4}{*}{ B } & 7 & $94.22 \pm 0.28^{a}$ & $-0.53 \pm 0.12^{\mathrm{ab}}$ & $7.29 \pm 0.33^{\mathrm{ab}}$ & $9.31 \pm 0.45^{\mathrm{a}}$ & $7.30 \pm 0.34^{\mathrm{ab}}$ & $94.17 \pm 0.74^{b}$ \\
\hline & 30 & $94.45 \pm 0.62^{\mathrm{a}}$ & $-0.52 \pm 0.00^{\mathrm{ab}}$ & $7.12 \pm 0.25^{b}$ & $9.04 \pm 0.58^{\mathrm{a}}$ & $7.13 \pm 0.25^{\mathrm{ab}}$ & $94.22 \pm 0.20^{\mathrm{b}}$ \\
\hline & 60 & $94.45 \pm 0.36^{\mathrm{a}}$ & $-0.51 \pm 0.05^{\mathrm{ab}}$ & $7.32 \pm 0.09 \mathrm{ab}$ & $9.20 \pm 0.30^{a}$ & $7.33 \pm 0.10^{\mathrm{ab}}$ & $93.98 \pm 0.38^{b}$ \\
\hline & 90 & $94.02 \pm 0.39^{a}$ & $-0.31 \pm 0.00^{\mathrm{ab}}$ & $6.60 \pm 0.19^{\mathrm{b}}$ & $8.91 \pm 0.10^{\mathrm{a}}$ & $6.61 \pm 0.19^{\mathrm{b}}$ & $92.68 \pm 0.07 \mathrm{bc}$ \\
\hline \multirow[t]{4}{*}{$\mathrm{C}$} & 7 & $94.79 \pm 0.73^{\mathrm{a}}$ & $-0.88 \pm 0.09 \mathrm{~cd}$ & $7.81 \pm 0.43^{\mathrm{ab}}$ & $9.43 \pm 0.77^{a}$ & $7.86 \pm 0.44^{\mathrm{ab}}$ & $96.45 \pm 0.30^{\mathrm{a}}$ \\
\hline & 30 & $93.32 \pm 0.04^{\mathrm{a}}$ & $-0.97 \pm 0.01^{\mathrm{d}}$ & $7.86 \pm 0.30^{\mathrm{ab}}$ & $10.36 \pm 0.20^{a}$ & $7.92 \pm 0.30^{\mathrm{ab}}$ & $97.03 \pm 0.37^{\mathrm{a}}$ \\
\hline & 60 & $93.81 \pm 0.38^{a}$ & $-0.89 \pm 0.02^{\mathrm{cd}}$ & $7.87 \pm 0.20^{\mathrm{ab}}$ & $10.05 \pm 0.40^{\mathrm{a}}$ & $7.92 \pm 0.20^{\mathrm{ab}}$ & $96.48 \pm 0.01^{\mathrm{a}}$ \\
\hline & 90 & $93.29 \pm 0.48^{a}$ & $-1.11 \pm 0.9^{\mathrm{d}}$ & $8.55 \pm 0.04^{\mathrm{ab}}$ & $10.93 \pm 0.33^{\mathrm{a}}$ & $8.62 \pm 0.04^{\mathrm{a}}$ & $97.39 \pm 0.13^{\mathrm{a}}$ \\
\hline
\end{tabular}

Değerler ortalama \pm standart sapma olarak verilmiştir.

Aynı sütundaki farklı harflerle gösterilen ortalamalar arasındaki fark istatistiksel olarak anlamlıdır $(P<0.05)$

$V$ alues are given as means \pm standard deviations.

The difference between the means indicated by different letters in the same column is statistically significant $(P<0.05)$

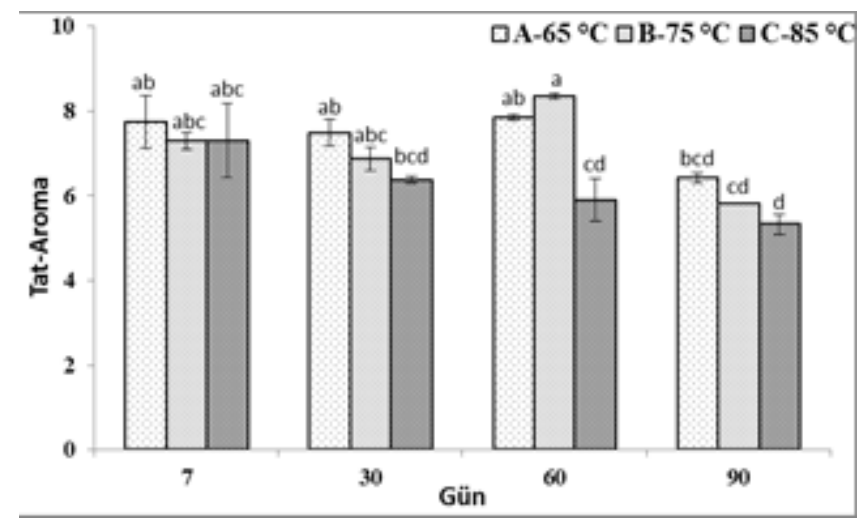



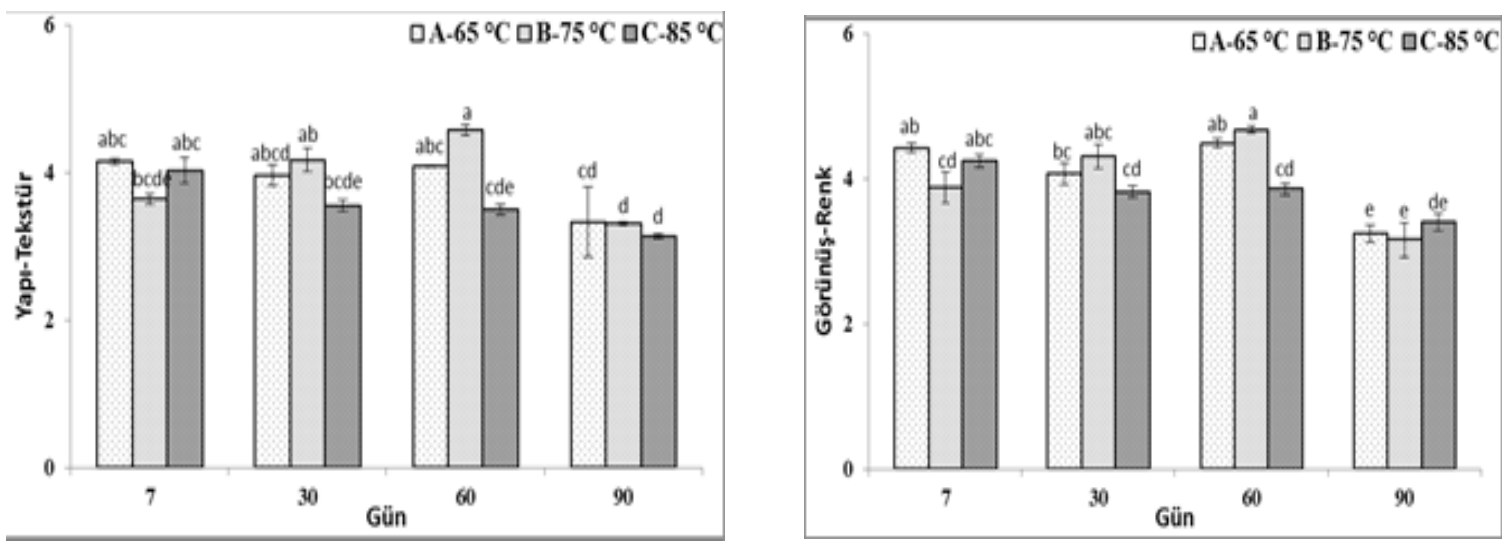

Şekil 3. Beyaz peynirlerin duyusal özelliklerinin depolama süresince değişimi Figure 3. Sensory properties variation of White cheeses during storage

\section{SONUÇ}

Süte uygulanan farklı pastörizasyon sicaklıkları, Beyaz peynirin dinamik reolojik analiz parametrelerini ve tekstür profil bileşenlerini depolama süresince etkilemiştir. $C$ ve $B$ peynirlerinin elastik özelliği, A’dan daha yüksek olmuştur. Sıcaklık artışı kazein protein etkileşimini arttırmışır. Depolama sırasında B peynirinin biyokimyasal etkiye bağlı değişim eğilimi $\mathrm{C}$ ve özellikle A'ya göre daha az olmuştur. C peynirinin devam eden süreçteki düşüşü ise yapısındaki denatüre peynir altı suyu proteinin yüksek oranına bağlanmıştır. B peynirinin sertlik ve dış yapışkanlık değerleri de daha yüksek bulunmuştur. Renk parametreleri uygulanan sicaklıklara bağlı değişmemiştir. Duyusal analizler açısından B peynirinin Yap1-Tekstür özelliği 2 ay süresince daha yüksek puan alırken son ayda ise peynirlerin bu özelliği birbirine benzer bulunmuştur. Sonuç olarak bu çalışma, daha iyi bir viskoelastik özellikte Beyaz peynir üretiminin $75{ }^{\circ} \mathrm{C}$ sıcaklığında pastörizasyon işlemi ile sağlanabileceğini göstermiştir. Ancak uygun sıcaklık ve sürenin peynirin bileşenlerine göre değişeceği ve düşük yağlı peynirlerin arzu edilen viskoelastik karakterlerinin karşılanmasında bu çalışmadaki yaklaşımın katkı sağlayacağı düşünülmektedir.

\section{ÇIKAR ÇATISMASI BEYANI}

$\mathrm{Bu}$ makalede yazarların, diğer kişilerin ve kurumların arasında bir çıkar çatışması yoktur.

\section{YAZAR KATKILARI}

OA çalışmayı tasarladı. OA ve AK analizleri gerçekleştirerek makaleyi yazdı. Tüm yazarlar makalenin yazımına katkıda bulundu, son halini okudu ve onayladi.

\section{TEŞEKKÜR}

Bu çalışma, 2140720 proje numarası ile Türkiye Bilimsel ve Teknolojik Araştırma Kurumu (TÜBİTAK) tarafindan desteklenmiştir. Peynir üretimlerinin yapıldığ Atatürk Orman Çiftliği’ne, reoloji ve tekstür analizlerinin gerçekleştirildiği Ondokuz May1s Üniversitesi’ne teknik desteklerinden dolayı teşekkür ederiz.

\section{KAYNAKLAR}

Ahmed, S. A., Wehaidy, H. R., Ibrahim, O. A., Abd El Ghani, S., El-Hofi, M. A. (2016). Novel milk-clotting enzyme from Bacillus stearothermophilus as a coagulant in UF-white soft cheese. Biocatal Agric Biotechnol, 7, 241-249, doi: https://doi.org/10.1016/j.bcab.2016.06.011.

Ak, M. M., Lokumcu-Altay, F. (2011). Peynirde Reoloji ve Tekstür. Peynir Biliminin Temelleri, Hayaloğlu \& B. Özer (baş ed.). Sidas Medya Ltd., İzmir, Türkiye s. 367-416.

Akalın, A. S., Karaman, A. D. (2010). Influence of packaging conditions on the textural and sensory characteristics, microstructure and color of industrially produced Turkish white cheese during ripening. J Texture Stud, 41(4), 549-562, doi: 10.1111/j.1745-4603.2010.00241.x. 
Al-Otaibi, M. M., Wilbey, R. A. (2006). Effect of chymosin reduction and salt substitution on the properties of white salted cheese. Int. Dairy J., 16(8), 903-909, doi: https://doi.org/10.1016/j.idairyj.2005.08.006.

Atasoy, A. F., Türkoğlu, H. (2008). Changes of composition and free fatty acid contents of Urfa cheeses (a white-brined Turkish cheese) during ripening: Effects of heat treatments and starter cultures. Food Chem, 110(3), 598-604, doi: https://doi.org/10.1016/j.foodchem.2008.02.04 6.

Benfeldt, C., Sørensen, J., Ellegård, K. H., Petersen, T. E. (1997). Heat treatment of cheese milk: Effect on plasmin activity and proteolysis during cheese ripening. Int. Dairy J., 7(11), 723731, doi: https://doi.org/10.1016/S09586946(97)00083-6.

Bryant, A., Ustunol, Z., Steffe, J. (1995). Texture of Cheddar cheese as influenced by fat reduction. J. Food Sci., 60(6), 1216-1219, doi: https://doi.org/10.1111/j.1365-

2621.1995.tb04559.x.

Cankurt, H. (2019). The effects of adding different stabilizers in brine on the physicochemical, sensory, microbiological and textural properties of white cheese. Foods, 8(4), doi: 10.3390 /foods 8040133 .

Drake, M. A., Gerard, P. D., Truong, V. D., Daubert, C. R. (1999). Relationship between instrumental and sensory measurements of cheese texture. I Texture Stud, 30(4), 451-476, doi: 10.1111/j.1745-4603.1999.tb00230.x.

Eroglu, A., Toker, O. S., Dogan, M. (2016). Changes in the texture, physicochemical properties and volatile compound profiles of fresh Kashar cheese ( $<90$ days) during ripening. Int J Dairy Technol, 69(2), 243-253, doi: 10.1111/1471-0307.12250.

Farbod, F., Kalbasi, A., Moini, S., EmamDjomeh, Z., Razavi, H., Mortazavi, A., Beheshti, H.-R. (2013). The effects of storage time on physiochemical, rheological, micro-structural and sensory properties of feta cheese fortified with fish and olive oils. J Nutr Food Sci, 3(5).
Florencia, F. S. (2013). Rheology of spreadable goat cheese made with autochthonous lactic cultures differing in their ability to produce exopolysaccharides. J Food Process Technol, 33(2), 233-238, doi: 10.1590/S010120612013005000034

Fox, P. F., McSweeney, P. L., Cogan, T. M., Guinee, T. P. (2004). Cheese: Chemistry, Physics and Microbiology, Volume 1, 3rd Edition, Academic Press, Elsevier, 640 p., ISBN: 9780122636523.

Fox, P. F., Uniacke-Lowe, T., McSweeney, P. L. H., O'Mahony, J. A. (2015). Dairy Chemistry and Biochemistry. 2nd Edition, Springer International Publishing, Switzerland, 584 p., ISBN: 978-3-31914891-5.

Frau, F., Font de Valdez, G., Pece, N. (2014). Effect of Pasteurization Temperature, Starter Culture, and Incubation Temperature on the Physicochemical Properties, Yield, Rheology, and Sensory Characteristics of Spreadable Goat Cheese. Journal of Food Processing, 2014, 705746, doi: 10.1155/2014/705746.

Giri, S. K., Tripathi, M. K., Kotwaliwale, N. (2018). Effect of composition and storage time on some physico-chemical and rheological properties of probiotic soy-cheese spread. J Food Sci Technol, 55(5), 1667-1674, doi: 10.1007/s13197-018-30781.

Guinee, T. P., Auty, M. A. E., Fenelon, M. A. (2000). The effect of fat content on the rheology, microstructure and heat-induced functional characteristics of Cheddar cheese. Int. Dairy J., 10(4), 277-288, doi: https://doi.org/10.1016/S0958-6946(00)000480 .

Guinee, T. P., Pudja, P. D., Farkye, N. Y. (1993). Fresh Acid-Curd Cheese Varieties. In Cheese: Chemistry, Physics and Microbiology, In P. F. Fox (chief ed.), Volume 2, Springer, Boston, USA, pp. 363-419.

Gunasekaran, S., Ak, M. M. (2000). Dynamic oscillatory shear testing of foods - selected applications. Trends Food Sci Technol, 11(3), 115127, doi: https://doi.org/10.1016/S09242244(00)00058-3. 
Guo, L., Van Hekken, D. L., Tomasula, P. M., Shieh, J., Tunick, M. H. (2011). Effect of salt on the chemical, functional, and rheological properties of Queso Fresco during storage. Int. Dairy J., 21(5), 352-357, doi: https://doi.org/10.1016/j.idairyj.2010.12.009.

Izli, N., Yildiz, G., Ünal, H., Işik, E., Uylaşer, V. (2014). Effect of different drying methods on drying characteristics, colour, total phenolic content and antioxidant capacity of Goldenberry (Physalis peruviana L.). Int J Food Sci Technol, 49(1), 9-17, doi: 10.1111/ijfs.12266.

Jalilzadeh, A., Hesari, J., Peighambardoust, S. H., Javidipour, I. (2018). The effect of ultrasound treatment on microbial and physicochemical properties of Iranian ultrafiltered feta-type cheese. J. Dairy Sci., 101(7), 5809-5820, doi: 10.3168/jds.2017-14352.

Jooyandeh, H., Goudarzi, M., Rostamabadi, H., Hojjati, M. (2017). Effect of Persian and almond gums as fat replacers on the physicochemical, rheological, and microstructural attributes of lowfat Iranian White cheese. Food Sci Nutr, 5(3), 669677, doi: 10.1002/fsn3.446.

Joshi, N. S., Jhala, R. P., Muthukumarappan, K., Acharya, M. R., Mistry, V. V. (2004). Textural and Rheological Properties of Processed Cheese. Int J Food Prop, 7(3), 519-530, doi: 10.1081/JFP200032962.

Kahyaoglu, T., Kaya, S. (2003). Effects of heat treatment and fat reduction on the rheological and functional properties of Gaziantep cheese. Int. Dairy J., 13(11), 867-875, doi: https://doi.org/10.1016/S0958-6946(03)001134.

Karaman, A. D., Akalın, A. S. (2013). Improving quality characteristics of reduced and low fat Turkish white cheeses using homogenized cream. Lebensm Wiss Technol, 50(2), 503-510, doi: https://doi.org/10.1016/j.lwt.2012.08.017.

Kessler, H. G. (1996). Lebensmittel-und Bioverfahrenstechnik-Molkereitechnologie, Verlag A. K.(chief ed.), München, 4, Germany, pp. 424454.
Koca, N., Metin, M. (2004). Textural, melting and sensory properties of low-fat fresh kashar cheeses produced by using fat replacers. Int. Dairy J., 14(4), 365-373, doi: https://doi.org/10.1016/j.idairyj.2003.08.006.

Lee, Y., Marshall, R. (1981). Microstructure and Texture of Process Cheese, Milk Curds, and Caseinate Curds Containing Native or Boiled Soy Proteins. J. Dairy Sci., 64(12), 2311-2317, doi: https://doi.org/10.3168/jds.S0022-

0302(81)82852-4.

Lemes, A. C., Pavón, Y., Lazzaroni, S., Rozycki, S., Brandelli, A., Kalil, S. J. (2016). A new milkclotting enzyme produced by Bacillus sp. P45 applied in cream cheese development. Lebensm Wiss Tecbnol, 66, 217-224, doi: https://doi.org/10.1016/j.lwt.2015.10.038.

Lucey, J. A., Johnson, M. E., Horne, D. S. (2003). Invited Review: Perspectives on the Basis of the Rheology and Texture Properties of Cheese. J. Dairy Sci., 86(9), 2725-2743, doi: https://doi.org/10.3168/jds.S0022-

0302(03)73869-7.

Park, Y. W., Juárez, M., Ramos, M., Haenlein, G. F. W. (2007). Physico-chemical characteristics of goat and sheep milk. Small Rumin. Res., 68(1), 88113 , doi: https://doi.org/10.1016/j.smallrumres.2006.09.0 13.

Ramírez-López, C., Vélez-Ruiz, J. F. (2018). Effect of Goat and Cow Milk Ratios on the Physicochemical, Rheological, and Sensory Properties of a Fresh Panela Cheese. J. Food Sci., 83(7), 1862-1870, doi: 10.1111/1750-3841.14195.

Rubel, I. A., Iraporda, C., Gallo, A., Manrique, G. D., Genovese, D. B. (2019). Spreadable ricotta cheese with hydrocolloids: Effect on physicochemical and rheological properties. Int. Dairy J., 94, 7-15, doi: https://doi.org/10.1016/j.idairyj.2019.03.002.

Rynne, N. M., Beresford, T. P., Kelly, A. L., Guinee, T. P. (2004). Effect of milk pasteurization temperature and in situ whey protein denaturation on the composition, texture and heat-induced functionality of half-fat Cheddar cheese. Int. Dairy 
J., 14(11), 989-1001, doi: https://doi.org/10.1016/j.idairyj.2004.03.010.

Sant'Anna, V., Gurak, P. D., Ferreira Marczak, L. D., Tessaro, I. C. (2013). Tracking bioactive compounds with colour changes in foods - A review. Dyes Pigm, 98(3), 601-608, doi: https://doi.org/10.1016/j.dyepig.2013.04.011.

Singh, H., Waungana, A. (2001). Influence of heat treatment of milk on cheesemaking properties. Int. Dairy J., 11(4), 543-551, doi: https://doi.org/10.1016/S0958-6946(01)000851.

Soltani, M., Boran, O. S., Hayaloglu, A. A. (2016). Effect of various blends of camel chymosin and microbial rennet (Rhizomucor miehei) on microstructure and rheological properties of Iranian UF White cheese. Lebensm Wiss Technol, 68, 724-728, doi: https://doi.org/10.1016/j.lwt.2016.01.028.
Spotti, M. J., Martinez, M. J., Pilosof, A. M. R., Candioti, M., Rubiolo, A. C., Carrara, C. R. (2014). Rheological properties of whey protein and dextran conjugates at different reaction times. Food Hydrocoll, 38, 76-84, doi: https://doi.org/10.1016/j.foodhyd.2013.11.017.

Türkmen, D. (2019). Farklı ticari rennetlerle üretilen beyaz peynirlerde olgunlaşma sırasında tekstürel, mikroyapisal ve biyokimyasal değişimler. Hatay Mustafa Kemal Üniversitesi Fen Bilimleri Enstitüsü Gıda Mühendisliği Anabilim Dalı Yüksek Lisans Tezi, Hatay,Türkiye, $168 \mathrm{~s}$.

Van Hekken, D. L., Tunick, M. H., Leggett, L. N., Tomasula, P. M. (2012). Impact of curd milling on the chemical, functional, and rheological properties of starter-free Queso Fresco1,2. J. Dairy Sci., 95(10), 5527-5535, doi: https://doi.org/10.3168/jds.2011-4933. 